\title{
Effect of Irrigation Management Practices of Rice Grown in North Central Plateau Climatic Zone of Odisha, India
}

\author{
D. K. Mohanty ${ }^{1}$, S. R. Dash ${ }^{2} *$ and J. Bhuyan ${ }^{1}$ \\ ${ }^{1}$ Krishi Vigyan Kendra, Mayurbhanj-II, Jashipur, Odisha \\ ${ }^{2}$ Krishi Vigyan Kendra, Malakngiri, Odisha \\ Odisha University of Agriculture and Technology, Bhubaneswar-03, India \\ *Corresponding author
}

\section{Keywords}

Puddling, Levelling,

Cyclic

submergence,

Tillering, Wetting,

Drying, Yield,

Gross return, Net

return, Benefit Cost

Ratio

Article Info

Accepted:

10 April 2020

Available Online:

10 May 2020

\section{A B S T R A C T}

Field experiments were conducted at farmer's field by Krishi Vigyan Kendra, Mayurbhanj, Shyamakhunta of Odisha to evaluate the irrigation water management practices on yield of rice on growth, yield and economics of transplanted rice during Rabi 2013-14 and 2014-15. The different treatments were taken as $\mathrm{T}_{1}$ - Control treatment, where puddling is done by desi plough and continuous submergence of water in paddy field throughout the crop period, $\mathrm{T}_{2}$ Puddling by bullock drawn puddler, levelling and continuous submergence of water in paddy field throughout the crop period and $\mathrm{T}_{3}$ - Puddling by bullock drawn puddler, levelling and cyclic submergence of water in paddy field throughout the crop period. The experiment revealed that the $\mathrm{B}$ : $\mathrm{C}$ ratio, gross return (Rs/ha) and net return (Rs/ha) were recorded the highest with the treatment $\mathrm{T}_{3}$ i.e. the plot where puddling is done by bullock drawn puddler, levelling and cyclic submergence of water in paddy field throughout the crop period during both the years. As per pooled data the net return (Rs. 26,150/- per ha) and B:C ratio (2.93) also recorded highest with the treatment $T_{3}$. The percentage increase in yield over control was found to be the highest in the treatment $T_{3}$ followed by $T_{2}$. Thus, among three methods tried $\mathrm{T}_{3}$ i.e. mechanical puddling and levelling and cyclic submergence of water in paddy field throughout the crop period is more productive, economical and sustainable.

\section{Introduction}

In India, rice occupies an area of $44 \mathrm{~m}$ ha with an average production of $90 \mathrm{~m}$ tonnes, with productivity of $2.0 \mathrm{t} / \mathrm{ha}$. Demand for rice is growing every year and it is estimated that in
$2025 \mathrm{AD}$, the requirement would be $140 \mathrm{~m}$ tones (Duttarganvi et al., 2016). According to the projections made by the Population Foundation of India, India's population will be 1,546 million by the end of 2030 . It is estimated that the demand for rice will be 
$121.2 \mathrm{~m}$ tonnes. In order to achieve this target, the productivity of rice has to be brought to the level of $3.3 \mathrm{t} / \mathrm{ha}$ from present level of 2.2 t/ha (Anjani et al., 2014).

In state Odisha, Rice covers about $69 \%$ of the cultivated area and is the major crop, covering about $63 \%$ of the total area under food grains. It is the staple food of almost the entire population of Odisha; therefore, the state economy is directly linked with improvements in production and productivity of rice in the state. The state is located in the subtropical belt of India.

Rice is typically grown in bunded fields that are continuously flooded up to 7-10 days before harvest. Continuous flooding ensures adequate water and control weeds in the rice field. For producing rice at present with traditional irrigation techniques, large quantities of water are being used to flood paddy fields with standing water $2-5 \mathrm{~cm}$ deep at the different stages of crop growth. Studies have indicated that 3000-5000 liters of water are often used to produce $1 \mathrm{~kg}$ of rice (Satyanarayana et al., 2004), but this includes water applications which are clearly excessive. According to an estimation made by International Rice Research Institute (IRRI), on an average 1,432 liters of water is needed to produce $1 \mathrm{~kg}$ of rice in an irrigated lowland production system (Anonymous, 2009).

Mostly, rice is first raised in a separate seedbed and subsequently transplanted into the rice field when the seedlings are 2-3 weeks old. Water losses by seepage and percolation account for about $25-50 \%$ of all water inputs in heavy soils with shallow groundwater tables of 20-50 cm depth (Dong et al., 2004), and 50-85\% in coarse-textured soils with deep groundwater tables of $1.5 \mathrm{~m}$ depth or more (Singh et al., 2002). This is about three times more than for growing wheat and maize (Riaz, 2001). Only transpiration is a productive water flow as it contributes to crop growth and development. Thorough puddling results in a good compacted soil that reduces permeability and percolation rates throughout the crop growing period (Tuong et al., 1994). In saturated soil culture (SSC), the soil is kept as close to saturation as possible, thereby reducing the hydraulic head of the ponded water, which decreases the seepage and percolation flows. Tabbal et al., (2002) reported water savings under SSC in transplanted and direct wetseeded rice in puddled soil and Bouman and Tuong (2001) found that water input decreased on average by $23 \%$ (5\% to $50 \%$ ) from the continuously flooded check, with a non-significant yield reduction of $6 \%$ on average in direct dry-seeded rice in nonpuddled soil. Alternate wetting and drying (AWD), irrigation water is applied to obtain flooded conditions after a certain number of days have passed with the disappearance of ponded water. Research in more loamy and sandy soils with deeper groundwater tables in India and the Philippines showed reductions in water inputs of more than $50 \%$ coupled with yield loss of more than $20 \%$ compared with the flooded check (Singh et al., 2002 and Tabbal et al., 2002). Water scarcity is a major challenge affecting rice production all around the globe. More than $80 \%$ of the fresh water resources in Asia are used for agriculture, of which about half of the total irrigation water is used for rice production (Dawe et al., 2003). Future rice production will depend on improvements in water use efficiency for growing rice crops.

After identifying all these water related issues in rice cultivation in Mayurbhanj district of Odisha, an On Farm Testing (OFT) has been designed by Krishi Vigyan Kendra, Mayurbhanj-I to assess irrigation management practices of rice grown in North Central Plateau climatic zone of Odisha. 


\section{Materials and Methods}

The present study was conducted in seven locations of Mayurbhanj district during Rabi, 2013-14 and 2014-15 by KVK, Mayurbhanj-I in the form of On Firm Trial (OFT) in the farmer's field. Seven farmers were selected in same agro-ecological situation in both the years. The soil type of the experimental site was sandy loam with organic carbon content of $5.3 \%$ with low $\mathrm{pH}$ of 5.42 . The treatments consisted of $\mathrm{T}_{1}$ - Control treatment, where puddling is done by desi plough and continuous submergence of water in paddy field throughout the crop period, $\mathrm{T}_{2}$ - Puddling by bullock drawn puddler, levelling and continuous submergence of water in paddy field throughout the crop period and $T_{3}-$ Puddling by bullock drawn puddler, levelling and cyclic submergence of water in paddy field throughout the crop period. After the establishment stage, cyclic $5 \mathrm{~cm}$ submergence of water has to be continued throughout the crop period. Irrigation is to be given days after disappearance of ponded water. The experiment was conducted with 125-days rice variety Lalat. Twenty five days old seedlings at $25 \times 10 \mathrm{~cm}$ spacing was transplanted in each years of experiment.

Seedlings were raised in nursery in accordance with establishment methods. Seeds were soaked for $24 \mathrm{hr}$ and incubated in moist gunny bags for 2 days. Pre-germinated seeds were broadcasted uniformly on nursery beds and soil with farmyard manure mixture (1:1) was spread in a thin layer. The beds were irrigated daily and thoroughly before lifting the seedlings. Pre-emergent application of Butachlor (50\% $\mathrm{EC)} \mathrm{@} 1 \mathrm{~kg}$ a.i./ha, followed by early post-emergent application of Bispyribac sodium (10\% EC) @ $0.025 \mathrm{~kg}$ a.i./ha at 25-30 DAT. Irrigation treatments were isolated with buffer channels, so that water movement can be effectively controlled and managed. Fertilizer dose $80-40-40 \mathrm{~kg}$
NPK/ha was applied for all the plots based on soil test based fertilizer recommendation. Half the recommended dose of $\mathrm{N}$ and full dose of $\mathrm{P}$ and $\mathrm{K}$ were applied basal and remaining $\mathrm{N}$ was applied in 2 equal splits at 30 and 60 DAT. The characteristic of technology was maintaining $2 \mathrm{~cm}$ of water up to seven days of transplanting in the crop field and after the establishment stage, cyclic submergence of water up to $5 \mathrm{~cm}$ and submergence has to be continued throughout the crop period. A common dose of fertilizer was used in all the treatments and line transplanting was done in all plots under experiment. Observations were recorded for various yield and yield attributing characters. The economics of different treatments were worked out by considering the present market price of the inputs and produces. All recommended agronomical practices were employed from time to time (Das, 2012).

\section{Results and Discussion}

Yield is the complex character and it depends on many morphological and bio-chemical events that occur within plant during the crop growth and development. Result from the present experiment indicated that grain yield of rice was significantly influenced by irrigation water management practices (Table 1) and amongst the methods followed $T_{3}$ had its most significant effect on yield performance standpoint, which was (43.4 $\mathrm{q} \mathrm{ha}^{-1}$ ) (average of two years) in its highest peak and followed by $\mathrm{T}_{2}(38.6 \mathrm{q}$ ha- 1$)$ and $\mathrm{T}_{1}$ $\left(36.2 \mathrm{q} \mathrm{ha}^{-1}\right)$.

The treatment yields were significantly different with each other at 5\% level of significance with co-efficient of variation (CV) was 5.21. This may be due to more effective tillering development when there was no standing water in rice field. As far as yield attributing characters are concerned, $\mathrm{T}_{3}$ recorded highest numbers of effective 
tillers $/ \mathrm{m}^{2}(313 \pm 12)$ followed by $\mathrm{T}_{2}(276 \pm 17)$ and $\mathrm{T}_{1}(254 \pm 22)$. More numbers of filled grains per panicle (81.3) was also observed in case of $T_{3}$ followed by $T_{2}$ having 78.8 nos. of filled grain/panicle and less numbers of filled grains observed in control plots (76.4 per panicle). Increased growth and yield might be due to cyclic submergence of water, which has provided sufficient nutrients for vegetative and reproductive growth due to aeration and better root growth. These results confirm the findings of (Chandrapala et al., 2010). Zhang et al., 2009 in his experiment on alternate wetting and moderate soil drying in rice, concluded that there may be yield decline when the irrigation interval increased from 5 to 8 days.

Table.1 Effect of irrigation management practices of rice var. Lalat (Average data of two years)

\begin{tabular}{|c|c|c|c|c|c|c|c|c|c|c|}
\hline $\begin{array}{c}\text { Treatm } \\
\text { ents }\end{array}$ & $\begin{array}{c}\text { Plant } \\
\text { height at } \\
\text { maturity } \\
(\mathrm{cm})\end{array}$ & $\begin{array}{c}\text { Effective } \\
\text { tillers } / \mathbf{m}^{2} \\
\text { (nos.) }\end{array}$ & $\begin{array}{l}\text { Panicle } \\
\text { length } \\
\text { (cm) }\end{array}$ & $\begin{array}{c}\text { Filled } \\
\text { grain/ } \\
\text { panicle } \\
\text { (nos.) }\end{array}$ & $\begin{array}{c}1000 \\
\text { grain } \\
\text { weight } \\
(\mathrm{g})\end{array}$ & $\begin{array}{l}\text { Yield } \\
\text { (t/ha) }\end{array}$ & $\begin{array}{c}\text { Cost of } \\
\text { cultivati } \\
\text { on } \\
\left(\text { Rs ha }^{-1}\right)\end{array}$ & $\begin{array}{c}\text { Gross } \\
\text { return } \\
\left(\text { Rs ha }^{-1}\right)\end{array}$ & $\begin{array}{c}\text { Net } \\
\text { return } \\
\left(\text { Rs ha }^{-1}\right)\end{array}$ & $\begin{array}{c}\mathrm{BC} \\
\text { ratio }\end{array}$ \\
\hline $\mathbf{T}_{\mathbf{1}}$ & $97 \pm 8$ & $254 \pm 22$ & 18.62 & 76.4 & 23.8 & 3.62 & 27,900 & 45,250 & 17,350 & 1.62 \\
\hline $\mathbf{T}_{2}$ & $97 \pm 6$ & $276 \pm 17$ & 19.17 & 78.8 & 23.9 & 3.86 & 27,250 & 48,250 & 21,000 & 1.77 \\
\hline $\mathbf{T}_{\mathbf{3}}$ & $98 \pm 3$ & $313 \pm 12$ & 19.76 & 81.3 & 24.2 & 4.34 & 28,100 & 54,250 & 26,150 & 1.93 \\
\hline
\end{tabular}

Table.2 Economics of different treatments (Average data of two years)

\begin{tabular}{|c|c|c|c|c|}
\hline Treatments & $\begin{array}{l}\text { Grain yield, } \\
\left(\mathrm{t} \mathrm{ha}^{-1}\right)\end{array}$ & B:C ratio & $\begin{array}{l}\text { Gross return } \\
\left(\text { Rs ha }^{-1}\right)\end{array}$ & $\begin{array}{l}\text { Net return } \\
\left(\text { Rs ha }^{-1}\right)\end{array}$ \\
\hline$T_{1}$ & 3.62 & 1.62 & 45,250 & 17,350 \\
\hline $\mathbf{T}_{2}$ & 3.86 & 1.77 & 48,250 & 21,000 \\
\hline $\mathbf{T}_{3}$ & 4.34 & 1.93 & 54,250 & 26,150 \\
\hline \pm SEM & 0.1 & 0.05 & 1374 & 1374 \\
\hline
\end{tabular}

\section{Economics}

Economic viability is a function of gains and losses of production practices. The adoption of any technology in modern agriculture can only be feasible and acceptable to the farmers if it is economically viable. The detail results are given in Table 2 .

The results presented in Table 2 revealed that among irrigation water levels $\mathrm{T}_{3}$ recorded higher benefit: cost ( $\mathrm{B}: \mathrm{C}$ ratio) over the other treatments and were proved to be the most effective and gave the highest yield. Singh et al., (2002) found similar results from his experiment conducted on effects of rice establishment methods on crop performance, water use, and mineral nitrogen. Amongst the three treatments, $\mathrm{T}_{3}$ fetched the maximum gross returns $\left(54,250 \mathrm{Rs} \mathrm{ha}^{-1}\right)$ and net profit $\left(26,150 \mathrm{Rs} \mathrm{ha}^{-1}\right)$ with the highest $\mathrm{B}$ : $\mathrm{C}$ ratio (1.93). Gross returns of 48,250 Rs ha ${ }^{-1}$, net profit of 21,000 Rs ha ${ }^{-1}$ and B: C ratios of 1.77 were recorded in the plot managed by flood irrigation with puddling by bullock drawn puddler $\left(\mathrm{T}_{2}\right)$. In case of control plot $\left(\mathrm{T}_{1}\right)$ gross returns and net profit was 45,250 $\mathrm{Rs} \mathrm{ha}^{-1}$ and 17,350 Rs ha ${ }^{-1}$ respectively with $\mathrm{B}: \mathrm{C}$ ratio of 1.62. From the analysis it is revealed that among the treatments gross return, net return and $\mathrm{B}: \mathrm{C}$ ratio are significantly differ with each other at 5\% level of significance. This may be due to more yields and less cost of cultivation in $T_{3}$ treatment, in comparison to 
other treatments $T_{2}$ and $T_{1}$. The co-efficient of variation in case of gross return, net return and $\mathrm{BC}$ ratio are 5.22, 11.95 and 5.25 respectively.

Hence concluded, among three methods tried i.e. $\mathrm{T}_{1}$ - Control treatment, where puddling is done by desi plough and continuous submergence of water in paddy field throughout the crop period, $\mathrm{T}_{2}$ - Puddling by bullock drawn puddler, levelling and continuous submergence of water in paddy field throughout the crop period and $\mathrm{T}_{3}-$ Mechanical puddling and levelling and cyclic $5 \mathrm{~cm}$ submergence of water in paddy field throughout the crop period, treatment $T_{3}$ recorded significantly higher yield, gross return and much more effective over control. It enhanced rice yield and fetches higher returns as compared to other two treatments. The study concluded that irrigation water management, as one of the major factors which can pose a great influence on yield and net return of rice crop.

\section{References}

Anjani, K., Dasgupta, Pragna and Kumar, Rakesh. (2014). Emerging opportunities and challenges in rice production. Popular Kheti, 2(2): 6-11.

Anonymous. (2009). Rice Today. http://www. researchgate.net/publication/281474989 / How much water does rice use.

Bouman, B.A.M. and Tuong, T.P. (2001). Field water management to save water and increase its productivity in irrigated rice. Agric. Water Manage, 49:11-30.

Chandrapala, A.G., Yakadri, M., Mahender, K.R. and Bhupal Raj, G. (2010). Productivity and economics of rice (Oryza sativa L.)- maize (Zea mays L.) as influenced by methods of crop establishment, $\mathrm{Zn}$ and $\mathrm{S}$ application in rice. Indian J. of Agronomy, 55(3): 171176.
Das, S.R. (2012). Rice in Odisha. IRRI Technical Bulletin No. 16. Los Baños (Philippines): International Rice Research Institute. P. 31.

Dawe, D., Dobermann, A., Ladha, J.K., Yadav, R.L., Lin, B., Lal, P., Panaullah, G., Sariam, O., Singh, Y., Swarup, A., Zhen, Q.X. (2003). Does organic matter improve the sustainability and profitability of intensive rice systems. Field Crops Res., 83:191- 213.

Dong, B., Molden, D., Loeve, R., Li, Y.H., Chen, C.D. and Wang, J.Z. (2004). Farm level practices and water productivity in Zanghe irrigation system. Paddy Water Environ., 2: 217226.

Duttarganvi, S., Kumar, R.M., Desai, B.K. and Pujari, B.T. (2016). Influence of establishment methods, irrigation water levels and weed management practices on growth and yield of rice (Oryza sativa). Indian $J$. of Agronomy, 61(2):174-178.

Riaz, A. (2001). Crop Management in Pakistan. Department of Agriculture, Government of Punjab, Lahore.

Satyanarayana, A. and Babu, K.S. (2004). A revolutionary method of rice cultivation. (In) Manual on System of Rice Intensification (SRI), Acharya N.G. Ranga Agricultural University, Telangana, India. p.1.

Singh, A.K., Choudhury, B.U. and Bouman, B.A.M. (2002). Effects of rice establishment methods on crop performance, water use, and mineral nitrogen. In: Bouman, B.A.M., Hengsdijk, H., Hardy, B., Bindraban, P.S., Tuong, T.P., Ladha, J.K., editors. Water-wise rice production. Los Baños (Philippines): International Rice Research Institute. p 237-246.

Tabbal, D.F., Bouman, B.A.M., Bhuiyan, S.I., Sibayan, E.B. and Sattar, M.A. (2002). On-farm strategies for reducing water 
input in irrigated rice: case studies in the Philippines. Agric. Water Manage., 56:93-112.

Tuong, T.P., Wopereis, M.C.S., Marquez, J. and Kropff, M.J. (1994). Mechanisms and control of percolation losses in irrigated puddled rice fields. Soil Sci.
Soc. Am. J., 58:1794-1803.

Zhang, H., Xue, Y.G., Wang, Z.Q. and Yang, J.H. (2009). An alternate and moderate soil

drying regime improves root and shoot growth in rice. Crop Science49 (2): 246-260.

\section{How to cite this article:}

Mohanty, D. K., S. R. Dash and Bhuyan, J. 2020. Effect of Irrigation Management Practices of Rice Grown in North Central Plateau Climatic Zone of Odisha, India. Int.J.Curr.Microbiol.App.Sci. 9(05): 1179-1184. doi: https://doi.org/10.20546/ijcmas.2020.905.130 